\title{
Extractive Content and Colour Properties of 11-Year-Old Superior Teak Wood
}

\author{
Ganis Lukmandaru, Alfian Nur Falaah, Tomy Listyanto, and Dian Rodiana
}

\begin{abstract}
As a fancy wood, teak is valued for beautiful grain and color. However, there is a lack of understanding about the properties of fast-growing teak trees harvested in young stage. In addition, wood variation in vertical direction is less investigated. Therefore, the objective of this research was to assess superior teak woods (11 years, 5 trees) grown in Pemalang FMU in vertical and radial positions for its extractive contents and colour. Extractions were conducted using a sequence of toluene, ethanol, and hot water. The color evaluation was performed using CIEL ${ }^{*}{ }^{*}{ }^{*}{ }^{*}$ 's chromaticity system. The contents of toluene-extract, ethanol extract, hot-water extract, and total extractive ranged between 1.16 5.00\%; 0.29 1.04\%, and $0.98 \sim 2.35 \%$, and $4.03 \sim 7.31 \%$, respectively. For color properties, the brightness $\left(\mathrm{L}^{*}\right)$, redness $\left(\mathrm{a}^{*}\right)$, and yellowness $\left(\mathrm{b}^{*}\right)$ indices ranged from 49.50 57.42, 6.08 10.81, and 20.47 25.74, respectively. Toluene- and total extractive contents were greater in heartwood than in sapwood, while the reverse occurred for the hot-water extractive content. Toluene- and total extractive contents were higher in outer heartwood than in inner heartwood. With regard to colour properties, $L^{*}$ and $a^{*}$ values were significantly differed between sapwood and heartwood. Vertical stem analysis of samples obtained at bottom, center, and top showed the toluene extractive content, total extractive content, and $\mathrm{a}^{*}$ levels of center part of the tree were found to be lower than other parts. The $L^{*}$ were negatively correlated with extractive contents, with the highest correlation degree ($0.83^{* *}$ ) being observed in the total extractive content in the heartwood. This comparatively high level of correlation might be useful to predict its extractive amount as well as its natural durability. It is also noticed that superior teak wood was less darker and extractive contents than the heartwood control of a 72-year-old tree.
\end{abstract}

Keywords : juvenile wood, fast-growing, axial variation, wood chemistry, Jati Plus Perhutani.

\section{Introduction}

Teak (Tectona grandis L.f) is a crucial wood resource in Indonesia. The value of teak wood depends on its high natural durability, weather resistance, and beautiful color. Therefore, teak is utilized for various products and outdoor purposes. The qualities of teak wood are undoubtedly derived from extractives in the heartwood (Yamamoto et al. 1998; Lukmandaru and Takahashi 2008; 2009). Many studies have investigated that quinones are responsible for bioactivity against termites and fungi (Haupt et al. 2003; Thulasidas and Bhat 2007; Niamké et al. 2012; Lukmandaru 2013; Ismayati et al. 2016). Meanwhile, the relationship between color properties and natural durability has been addressed by several researchers (Bhat et al. 2005; Kokutse et al. 2006; Lukmandaru and Takahashi 2008).

The superior teak wood (Jati Plus Perhutani) from vegetative propagation has been utilized for various products. The trees were characterized by their fastergrowing nature, unlike conventional trees. So far, superior teak wood has been harvested early. The teak wood from young trees is associated with a paler color and lower natural durability (Bhat and Florence 2003; Lukmandaru and Takahashi 2008). Unfortunately, there is little information about the color and natural durability of superior teak or fastgrowing teak wood. Consumers necessarily have the basic knowledge to utilize these woods and produce the best advantages. Previously, the chemical components of superior teakwood (15 years) have been investigated (Lukmandaru et al. 2016). Furthermore, the relationship of the extractive content and color porperties of teak wood from young trees has been addressed but no clear pattern was found (Lukmandaru and Sayudha 2019; Zulkahfi et al. 2020). This study aimed to determine the extractive contents and color properties of superior teakwood. A factorial design was used to investigate the effects and interaction of vertical and radial positions. This study also discussed the correlation between the extractives' contents and the woods' colors.

\section{Materials and Methods}

The experiment was conducted in an 11-year-old teak stand (diameter breast height $=19.5 \sim 27.8 \mathrm{~cm}$, heartwood proportion $=76.7 \sim 85.7 \%$, growth rate $=1.77 \sim 2.52 \mathrm{~cm} /$ year) located in compartment 49, KRPH Klapanunggal, BKPH Banjar Sari, Pemalang Forest Management Unit, Central Java Province. The trees were selected to represent the young stage and currently were available in the market. All trees had been girdled for 13 months and five free-defect trees were felled at December 15, 2016. A 5-cm-thick disc was removed at three different vertical positions from the trees (Fig. 1). Each disc was divided into three parts: sapwood (SW), outer heartwood $(\mathrm{OH})$, and inner heartwood $(\mathrm{IH})$. Each part was converted into wood meal (40 60 mesh size) to determine the extractives content and color properties. The specimens from two cardinal radii (northsouth) were then combined to form a single sample. Sample meals were also prepared from the heartwood of a 72-yearold tree (bottom part) located Randublatung FMU, Central 
Java Province, for comparative purposes (control). This mature tree was expected to give sharp differences from the

young trees.

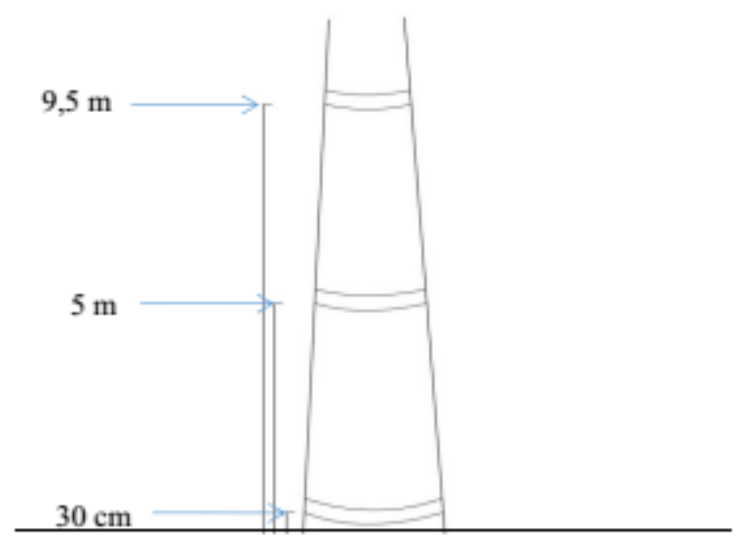

Figure 1. Diagrammatic illustration of discs removed from the vertical position of the tree.

\section{Determination of Extractive Contents}

Three grams of dried wood powder was successively extracted with toluene, ethanol, and hot water. The extractions were conducted using a 6 -h sequence of toluene and ethanol using a Soxhlet apparatus. Hot-water extractives content was determined following the ASTM D1110-1981 standard method. The solvents were concentrated in a rotary film evaporator, dried, and weighed to determine the toluene, ethanol, and hot-water extractive contents based on the oven-dry wood meal $(\mathrm{m} / \mathrm{m})$. The total of extractive contents was calculated by determining the sum of all extractive contents.

\section{Color Measurement}

The wood color was measured in the air-dried wood powder using an NF333 spectrocolorimeter (Nippon Denshoku Ind. Co Ltd.) with an opening diameter of $6.0 \mathrm{~mm}$. Moreover, this measurement employed the CIE standard illuminant D65 and a tungsten halogen light source. The percentage of reflectance data was collected at $10-\mathrm{nm}$ intervals over the visible spectrum $(400 \sim 700 \mathrm{~nm})$. Three measurements were made for each part. The value $L^{*}$ described psychometric lightness ( $0=$ black to $100=$ white). The value $a^{*}$ described the redness from the axis red $(+)$ to green $(-)$. Meanwhile, the value $b^{*}$ describes the yellowness from the $Y$ axis yellow $(+)$ to blue $(-)$.

\section{Statistical Analysis}

The variation in the extractive contents and color properties was analyzed by two-way analysis of variance (ANOVA) followed by Duncan's multiple range test $(p=$ 0.05). Meanwhile, the relationship between the independent variables was investigated using Pearson's correlation analysis. The data were analyzed by using SPSS-Win 16.0.

\section{Results and Discussion}

\section{Extractive Contents}

Extractive contents were obtained by successive extraction from apolar to polar solvents. Then, total extractive content was calculated. The values of toluene extractive, ethanol extractive, and hot-water extractive contents respectively ranged from 1.16 5.00\%, $0.29 \sim 1.04 \%$, and $0.98 \sim 2.35 \%$ (Table 1). It is found that toluene extractive content showed wider range compared to others. These values were lower than the corresponding values of control heartwood, particularly the values of toluene- and ethanol extractive contents. The corresponding values of toluene extractive content (TEC) of this study were within the range, unlike the values of previous studies. Meanwhile, the values of ethanol extractive content (EEC) were lower than those of 8 and 31 year-old teak wood in community forest and 51-year-old teak wood from Perhutani plantation stand (Lukmandaru and Takahashi 2008). In addition, the values of hot-water extractive content (HWC) were within the range, unlike the values of teak from Perhutani (class age III V) as reported by Lukmandaru (2010; 2016).

Total extractive content (TOC) of superior teak heartwood was considerably lower (4.03 7.31\%) than that of the control mature heartwood $(13.43 \%)$. These values were also lower than those of other mature teak heartwoods from Perhutani by 7.15-9.17\% (Lukmandaru and Takahashi 2008) and 10.57 12.62\% (Lukmandaru 2016). Regardless of the different sites, these findings correspond to the agerelated trend generally observed by wood chemists.

The ANOVA of extractive contents showed no significant vertical and radial position interactions (Table 2). The radial direction denoted that heartwood and sapwood had statistically distinctive TEC, HWC, and TOC. Furthermore, TEC and TOC levels in the IH differed significantly from those in the $\mathrm{OH}$ (Fig. 2 and 3). The 
significant difference between $\mathrm{OH}$ and $\mathrm{IH}$ was also observed for mature teakwood but not for juvenile teakwood in an earlier report (Lukmandaru and Takahashi 2008). It indicates that synthesis and accumulation of extractives during heartwood formation are more intense in the outer heartwood region or more mature in the superior teak.

The ANOVA revealed that the vertical direction had significant differences. The TEC and TOC levels in the bottom and top parts were higher than those in the center part. The high content of TEC and TOC in the bottom part was probably caused by intense polymerization reactions during the aging process of the tree. Meanwhile, the high content in the top part was caused by the vicinity to the crown part as the photosynthesis site. The significant differences in vertical direction were also found in eucalypt hybrid urograndis from Brazil (Gominho et al. 2001). Yunanta et al. (2014) measured an increase in an ethanoltoluene extract with tree height of shorea species.

The EEC and HWC level variations in different vertical directions were insignificant. This finding suggested that high molecular weight phenolics and sugars remained steady with height. The patterns of HWC levels were similar to those of Siberian larch wood, which had no systematic differences in vertical position (Neverova et al. 2013). HWC tended to increase from the bottom to the top part in Robinia pseudoacacia (Adamopoulos et al. 2005). This finding differs from the present investigation's results.

Table 1. Extractive contents and color properties of superior teak wood (11 years, mean of 5 trees) as compared with a mature control. The same letters on the same column are not statistically different at $P<0.05$ by Duncan's test.

\begin{tabular}{lcccccccc}
\hline & & \multicolumn{3}{c}{ Extractive content (\%) } & \multicolumn{3}{c}{ Colour properties } \\
\hline Vertical & Radial & TEC & EEC & HWC & TOC & $L^{*}$ & $\mathrm{a}^{*}$ & $\mathrm{~b}^{*}$ \\
\hline Bottom & Sapwood & 1.74 & 0.29 & 2.53 & 4.57 & 60.87 & 6.94 & 20.47 \\
& Outer heartwood & 4.95 & 0.45 & 1.27 & 6.67 & 51.07 & 10.07 & 23.66 \\
& Inner heartwood & 4.02 & 0.36 & 1.14 & 5.52 & 52.64 & 10.81 & 23.18 \\
& Average & $3.57 \mathrm{~b}$ & 0.37 & 1.65 & $5.59 \mathrm{~cd}$ & 54.86 & $9.27 \mathrm{~g}$ & 22.44 \\
\hline Center & Sapwood & 1.43 & 0.39 & 1.91 & 3.73 & 64.45 & 6.08 & 20.61 \\
& Outer heartwood & 4.03 & 0.39 & 0.98 & 5.73 & 51.97 & 9.94 & 24.34 \\
& Inner heartwood & 2.18 & 0.84 & 1.00 & 4.03 & 57.42 & 9.87 & 23.96 \\
& Average & $2.55 \mathrm{a}$ & 0.54 & 1.30 & $4.50 \mathrm{c}$ & 57.95 & $8.63 \mathrm{f}$ & 22.97 \\
\hline Top & Sapwood & 1.16 & 0.74 & 1.89 & 3.78 & 64.50 & 6.41 & 25.74 \\
& Outer heartwood & 5.00 & 1.04 & 1.18 & 7.31 & 49.50 & 10.48 & 24.86 \\
& Inner heartwood & 3.35 & 0.93 & 1.21 & 6.18 & 50.80 & 10.55 & 24.03 \\
& Average & $3.34 \mathrm{~b}$ & 0.90 & 1.43 & $5.76 \mathrm{~d}$ & 54.93 & $9.14 \mathrm{~g}$ & 24.87 \\
\hline Control & Heartwood (72 years) & 8.20 & 2.64 & 2.59 & 13.43 & 41.57 & 10.63 & 24.27 \\
\hline
\end{tabular}

Remarks: TEC = toluene extractive content, $\mathrm{EEC}=$ ethanol extractive content, $\mathrm{HWC}=$ Hot-water extractive content, $\mathrm{TOC}=$ total extractive content.

Table 2. Vertical and radial direction analysis of variance in extractive contents and color properties of superior teak wood.

\begin{tabular}{lcccccccc}
\hline & $\mathrm{df}$ & \multicolumn{7}{c}{ Mean square } \\
\cline { 3 - 8 } Source of variation & & TEC & EEC & HWC & TOC & $\mathrm{L}^{*}$ & $\mathrm{a}^{*}$ & $\mathrm{~b}^{*}$ \\
\hline Vertical position (A) & 2 & $4.36^{*}$ & 1.02 & 0.47 & $6.34^{*}$ & 45.17 & $1.69^{*}$ & 24.59 \\
Radial position (B) & 2 & $38.39^{*}$ & 0.29 & $4.83^{* *}$ & $22.34^{*}$ & $622.24^{*}$ & $72.45^{*}$ & 15.65 \\
A x B & 4 & 1.52 & 0.05 & 0.18 & 1.52 & 24.17 & 0.36 & 11.52 \\
Error & 36 & 0.77 & 0.35 & 0.56 & 1.74 & 16.88 & 0.40 & 13.16 \\
\hline
\end{tabular}

Remarks: TEC = toluene extractive content, $\mathrm{EEC}=$ ethanol extractive content, $\mathrm{HWC}=$ Hot-water extractive content, $\mathrm{TO} \mathrm{C}=$ total extractive content. ${ }^{* *}$ Significant at the $1 \%$ level; ${ }^{*}$ significant at the $5 \%$ level

Toxic quinones were mostly detected in apolar fraction, while the predominantly sugar (mono- and disaccharides) and sugar derivatives were identified in the methanol extracts (Windeisen et al. 2003; Lukmandaru and Takahashi 2009). The low amounts of TEC and TOC probably cause lower natural durability in superior teakwood than in conventional mature teaks. The sapwood part in radial position or the center part in vertical position was susceptible. Many studies have discovered the relationships between extractive contents and resistance against termite or fungi (Haupt et al. 2003; Lukmandaru and Takahashi 2008; 2009; Lukmandaru 2011). Niamké et al. (2011) measured high concentrations of starch and low molecular weight sugars in the teak sapwood. The high levels of HWC in the sapwood might reduce the natural durability against fungi. This study found that the sapwood proportion in the superior teak samples was $20 \%$ to $40 \%$. 

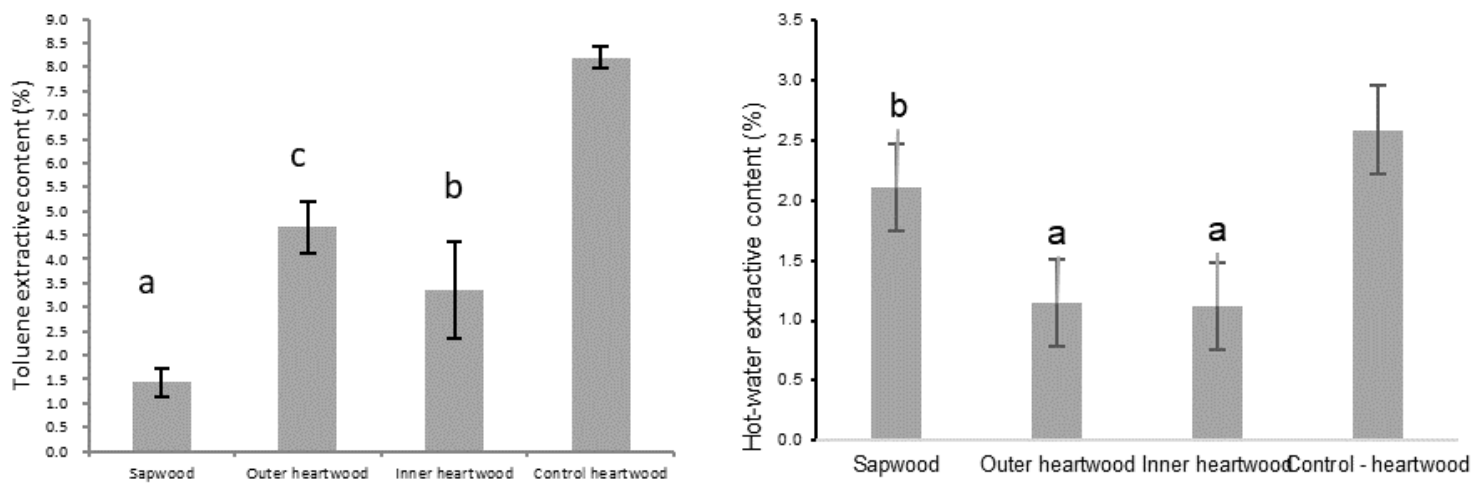

Figure 2. Extractive content obtained by successive extraction properties of superior teakwood (11 years) by radial position. Mean of 5 trees, with the standard deviation error bar. The same letters on the same graphic are not statistically different at $P<0.05$ by Duncan's test.
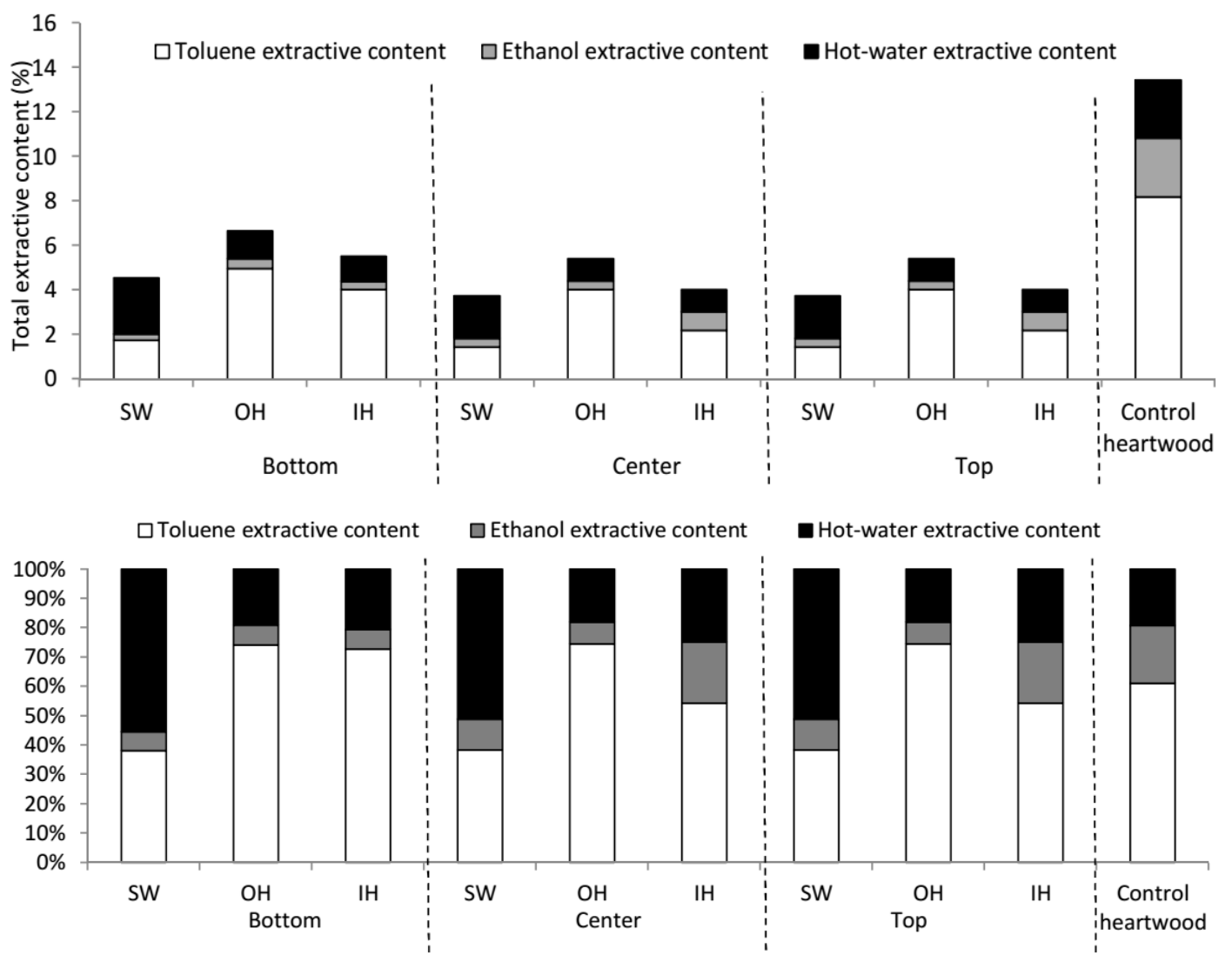

Figure 3. Total extractive content obtained by successive extraction of superior teakwood ( 11 years) based on oven-dry wood meal (upper) and extractive weight (lower). Remark : SW = sapwood; $\mathrm{OH}=$ outer heartwood, $\mathrm{IH}=$ inner heartwood.

Based on extractive weight, a clear distinction between sapwood and heartwood was found in TEC and HWC levels. The TEC level of the sapwood did not exceed $40 \%$, and the HWC level of the heartwood did not exceed $30 \%$ (Fig. 3). The similarity between superior teak heartwood and mature heartwood control was the composition of extractive content of $\mathrm{IH}$ in the center and top parts. This finding showed the EEC levels were close to
$20 \%$, while the TEC levels did not exceed $70 \%$. IH in the bottom part was characterized by a high amount of TEC and a low amount of EEC. It is assumed that sapwood has low natural durability due to the low content of TEC and EEC. IH part did not exhibit a similar level of natural durability to $\mathrm{OH}$ in other studies (Kokutse et al. 2006; Bhat et al. 2005). Although the $\mathrm{IH}$ of superior teakwood has the similar extractive content composition to that of heartwood control 
samples, the mature and juvenile woods have different compositions and content of toxic components (Lukmandaru and Takahashi 2009).

\section{Color Properties}

The $L^{*} a^{*} b^{*}$ values of superior teakwood samples and heartwood control had no striking differences, except the $L^{*}$ parameter (Table 1). The control sample's heartwood region had a significantly darker color $\left(L^{*}=41.57\right)$ than the superior teakwood's $\left(L^{*}=49.50 \sim 57.42\right)$. These values agreed with the general assumption that the heartwood of younger trees was paler, regardless of their different sites (Lukmandaru 2009a; Gierlinger et al. 2004). Moreover, the obtained values were nearly similar to the values of mature teak wood trees grown in Perhutani (Lukmandaru 2016).
The ANOVA of color properties showed no significant vertical and radial position interactions (Table 2). However, the $L^{*}$ and $a^{*}$ values of sapwood and heartwood differed significantly (Fig. 4). The ANOVA also revealed no significant difference in heartwood $(\mathrm{OH}$ and $\mathrm{H})$. Lukmandaru and Takahashi (2008) reported a significant difference in $\mathrm{L}^{*}$ and $\mathrm{a}^{*}$ between $\mathrm{H}$ and $\mathrm{OH}$ of 51 -year-old teak trees; this finding differs from the present investigation's findings. Studies on color properties of teak have noted similar patterns (Kokutse et al. 2006; Moya and Berrocal 2010). These patterns were probably related to the similar composition of coloring matters of the superior teakwood although TEC and TOC levels of $\mathrm{OH}$ and $\mathrm{IH}$ were statistically different. Vertical stem analysis discovered that the center part had statistically lower $a^{*}$ values than others, but in a small magnitude (Table 1).
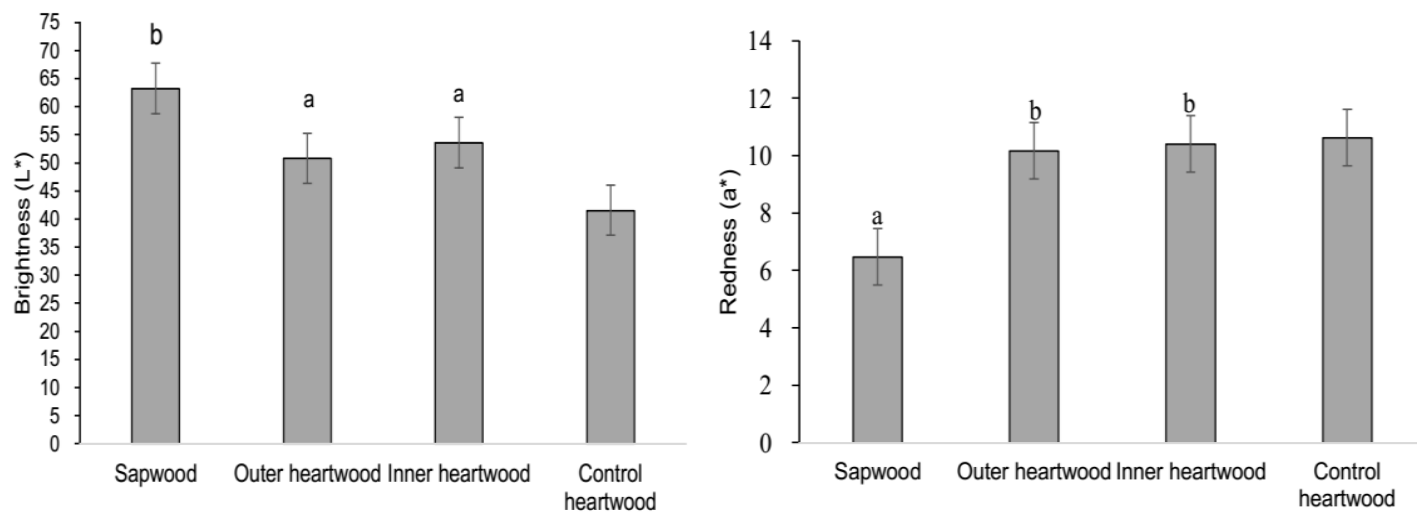

Figure 4. Color properties of superior teakwood (11 years) by radial position. Mean of 5 trees, with the standard deviation error bar. The same letters on the same graphic are not statistically different at $P<0.05$ by Duncan's test.

Table 3. Pearson's correlation coefficients between extractive contents and color properties of superior teakwood (11 years)

\begin{tabular}{|c|c|c|c|c|}
\hline & TEC & EEC & HWC & TOC \\
\hline \multicolumn{5}{|l|}{ Sapwood } \\
\hline Brightness $\left(\mathrm{L}^{*}\right)$ & -0.26 & 0.05 & $-0.66^{* *}$ & $-0.67^{* *}$ \\
\hline Redness $\left(a^{*}\right)$ & 0.19 & -0.15 & 0.37 & 0.36 \\
\hline Yellowness $\left(b^{*}\right)$ & -0.02 & 0.23 & -0.01 & 0.05 \\
\hline \multicolumn{5}{|l|}{ Heartwood } \\
\hline Brightness $\left(\mathrm{L}^{*}\right)$ & $-0.63^{* *}$ & $-0.55^{\star *}$ & -0.24 & $-0.83^{* *}$ \\
\hline Redness $\left(a^{*}\right)$ & $0.43^{*}$ & 0.17 & $0.41^{*}$ & $0.51^{\star *}$ \\
\hline Yellowness $\left(b^{*}\right)$ & 0.09 & -0.11 & -0.24 & -0.02 \\
\hline
\end{tabular}

Remark: TEC = toluene extractive content, EEC = ethanol extractive content, $\mathrm{HWC}=$ hot-water extractive content, $\mathrm{TOC}=$ total extractive content. ${ }^{* *}$ Significant at the $1 \%$ level; ${ }^{*}$ significant at the $5 \%$ level.

Wood color, together with beautiful grain, is an important quality parameter for teak. The inhomogeneity in vertical position (redness) and brighter heartwood in superior teak wood were certainly undesirable for several products (Table 1). Therefore, further research should modify superior teak wood to enhance its color properties. Heat treatment is used to improve the color properties and obtain a decorative specific dark color. So far, teak wood of young trees has been subjected to a heat treatment (Garcia et al. 2014). 

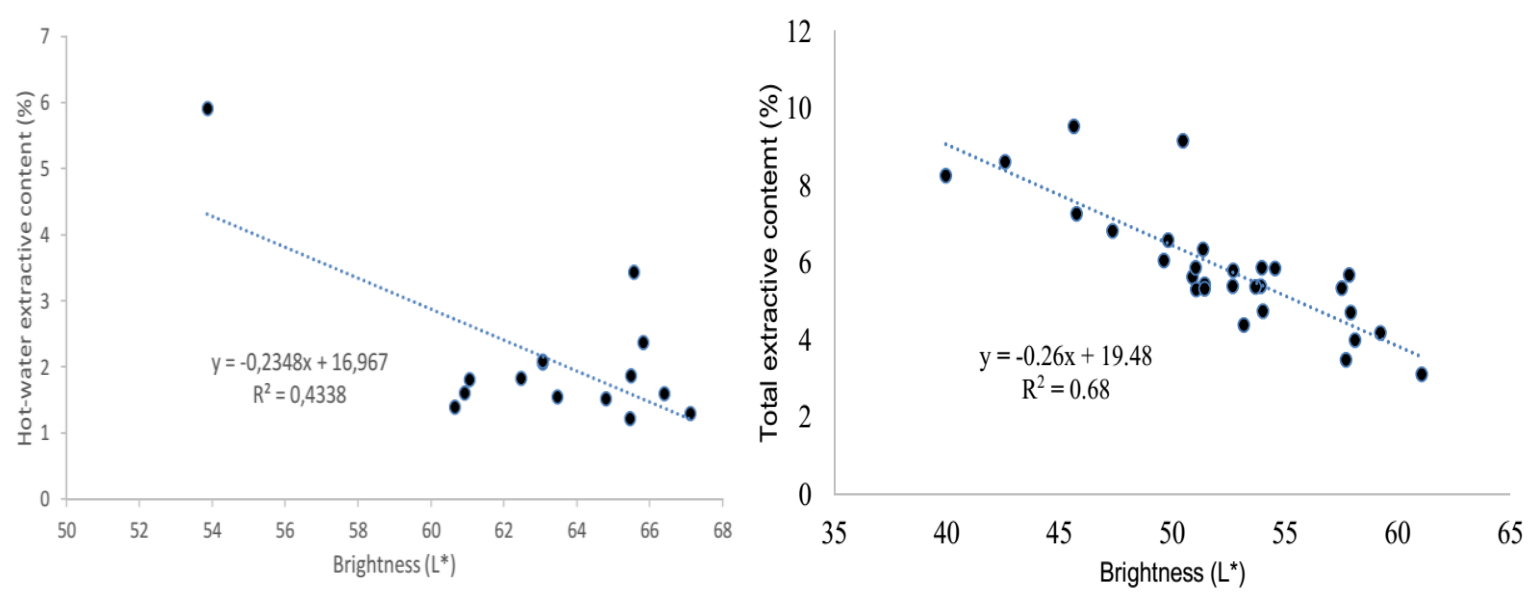

Figure 5. Scatterplots between hot-water extractive content and brightness (left) and between total extractive content and brightness (right) of superior teak wood (11 years).

\section{Relationship between Extractive Contents and Color Properties}

The correlation coefficient of sapwood and heartwood was considered as separated samples of color parameters and extractive contents. This correlation is summarized in Table 3. Table 3 confirms moderate negative correlation between the $L^{*}$ and HWC $\left(r=-0.66^{* *}\right)$ and between the $L^{*}$ and TOC $\left(r=-0.67^{* *}\right)$ in sapwood region. These slightly different values indicated that hot-water solubles mostly affected sapwood colors. This condition means that the sapwood contains more hot water soluble when it is darker (Fig. 5).

The measurement of $L^{*}$ and TOC values gained the highest negative correlation of $r=-0.83^{* *}$ in the heartwood region (Table 3). This strong correlation degree was a combination of apolar and polar fraction, as seen in the moderate negative correlation between $L^{*}$ and TEC $(r=-$ $\left.0.63^{* *}\right)$ or EEC $\left(r=-0.55^{* *}\right)$. These findings denote that the TEC and EEC contribute equally, and wood is darker when it contains more toluene and ethanol soluble extracts. The correlation analysis also revealed a moderate positive correlation between $a^{*}$ and TOC values, $a^{*}$ and TEC values, as well as $a^{*}$ and HWC values in the heartwood part. There was no significant relationship between the $b^{*}$ and extractive content parameters. This finding signifies that the parameter $a^{*}$ increases when TEC, HWC, and TOC values increase. Various TEC, HWC, and TOC levels caused various $a^{*}$ values in the vertical position (Table 1). The relationship between extractive contents and color properties $\left(\mathrm{L}^{*}\right.$ and $\left.\mathrm{a}^{*}\right)$ was also found in normal and black-streaked heartwood teak (Lukmandaru et al. 2009b; Lukmandaru 2011).

This study discovered significant correlations indicating that phenolics or coloring matters affected brightness and redness in apolar and polar fractions. A previous work by Lukmandaru (2016) found moderate correlations between $L^{*}$ and ethanol-benzene extracts $(r=$ $\left.0.60^{*}\right)$ as well as between $a^{*}$ and ethanol-benzene extracts $\left(r=0.39^{*}\right)$ of mature teak grown in Perhutani. These different correlation degrees occurred in juvenile and mature trees, particularly in their composition of coloring matters.

The $L^{*}$ was strongly correlated with the TOC $(r=$ 0.83 ), and thus, it was suitable for predicting the extractive amount (Fig. 5). The $n$-hexane and methanol extraction have detected several quinones (Lukmandaru 2013). Unfortunately, the contribution of quinones to wood color in teak has been less investigated. In addition, HWC was related to $L^{*}$ in sapwood and $a^{*}$ in the heartwood. The water-soluble coloring matters also remain unknown. The considerable differences of TEC and TOC levels between superior teak wood samples and mature heartwood control (Table 1) have corroborated these findings that teak wood color is associated with extractives' amounts. Many studies have found a positive correlation between the $L^{*}$ index and mass loss against termites (Lukmandaru and Takahashi 2008; Lukmandaru 2011) or against fungi (Kokutse et al. 2006) in teakwood. Therefore, further research necessarily investigates the use of fine teakwood and tests its natural durability.

Compared to the resuts of our parallel work (Zulkahfi et al. 2020) on superior teakwood (11 years) from Ngawi stand, several differences were found. The values of TEC and HWC in were higher but lower in ECC than those of Ngawi samples. Furthermore, the TOC values in top part in this experiment were higher. For color properties, with exception in top part, the heartwood of these Pemalang samples were darker than those of Ngawi woods. The differences pattern in longitudinal and radial variations on both extractive contents and color properties suggests a considerable geographical effect. With regard to relationship between extractive content and color properties, this finding confirm the significant correlation between $L^{*}$ and HWC in sapwood tissue of Ngawi sites. However, the similar pattern was not measured in the heartwood region, particularly in $L^{*}$ characteristic. In an earlier study (Lukmandaru and Sayudha 2019) for juvenile teakwood (5 and 7 years), HWC was 
moderately correlated with $a^{*}$ and $b^{*}$ levels (negatively) in heartwood part or with $L^{*}$ (negatively and $a^{*}$ (positively) in sapwood part. Therefore, it is assumed that color affecting phenolics in teakwood are varied in some extents even in young ages.

\section{Acknowledgement}

The authors are grateful to Perum Perhutani for its financial support of the research and Adminitrator of Ciamis FMU for providing the wood samples.

\section{Conclusions}

The investigation of all wood parameters (bottom, center, and top) showed that sapwood and heartwood had significantly different values in toluene extractive content, total extractive content, $L^{*}$, and $a^{*}$ values. Moreover, the outer heartwood and inner heartwood had significantly different toluene extractive content and total extractive content. The toluene extractive content, total extractive content, and $a^{*}$ levels of the trees' center part were significantly lower than those of the bottom and top parts. This study also demonstrated that superior teak wood exhibited significantly fewer extractive contents than the mature control. Furthermore, superior teak samples showed a considerably brighter appearance than the mature control. The $L^{*}$ was strongly correlated with total extractive content levels in the heartwood region, and $L^{*}$ was moderately correlated with hot-water extractive content in the sapwood region. The less extractive content and brighter color in the heartwood were probably related to its natural durability, which was an essential characteristic of heartwood's utilization.

\section{References}

Adamopoulos, S.; E. Voulgaridis; C. Passialis. 2005. Variation of Certain Chemical Properties within the Stemwood of Black Locust (Robinia pseudoacacia L.). Holz als Roh- und Werkstoff 63: 327-333.

Bhat, K.M.; E.J.M. Florence. 2003. Natural Decay Resistance of Juvenile Teak Wood Grown in High Input Plantations. Holzforschung 57: 453-455.

Bhat, K.M.; P.K. Thulasidas; E.J.M. Florence; K. Jayaraman. 2005. Wood Durability of Home-Garden Teak Against Brown-rot and White-rot Fungi. Trees 19: 654-660.

Garcia, R. A.; J. de Oliveira Lopes; A.M. do Nascimento; J.V. de Figueiredo Latorraca. 2014. Color Stability of Weathered Heat-Treated Teak Wood. Maderas Ciencia y tecnología 16(4): 453-462.

Gierlinger, N.; D. Jacques; M. Grabner; R. Wimmer; M. Schwaninger; P. Rozenberg; L.E. Paques. 2004. Colour of Larch Heartwood and Relationship to
Extractives and Brown-Rot Decay Resistance. Trees 18: 102-108.

Gominho, J.; J. Figueira; J.C. Rodrigues. 2001. Within-tree Variation of Heartwood, Extractives and Wood Density in the Eucalypt Hybrid Urograndis. Wood and Fiber Science 33: 3-8.

Haupt, M.; H. Leithoff; D. Meier; J. Puls; H.G. Richter; O. Faix. 2003. Heartwood Extractives and Natural Durability of Plantation-Grown Teak Wood (Tectona grandis L.f) - A case study. Holz als Roh- und Werkstoff. 61: 473-474.

Ismayati, M.; A. Nakagawa-Izumi; N.N. Kamaluddin; H. Ohi. 2016. Toxicity and Feeding Deterrent Effect of 2Methylanthraquinone from the Wood Extractives of Tectona grandis on the Subterranean Termites Coptotermes formosanus and Reticulitermes speratus. Insects 7:63

Kokutse, A.D.; A. Stokes; H. Bailleres; K. Kokou; C. Baudasse. 2006. Decay Resistance of Togolese teak (Tectona grandis L.f.) Heartwood and Relationship with Colour. Trees. 20: 219-223.

Lukmandaru, G.; K. Takahashi. 2008. Variation in the Natural Termite Resistance of Teak (Tectona grandis L. f.) Wood as a Function of Tree Age. Annals of Forest Science 65(7): 708p1-8

Lukmandaru, G.; K. Takahashi. 2009. Radial Distribution of Quinones in Plantation Teak (Tectona grandis L.f.). Annals of Forest Science 66(6): 605p1-p9.

Lukmandaru, G. 2009a. Sifat Kimia dan Warna Kayu Teras Jati pada Tiga Umur Berbeda. Jurnal IImu Teknologi Kayu Tropis. 7(1): 1-7.

Lukmandaru, G. 2009b. Pengukuran Kadar Ekstraktif dan Sifat Warna pada Kayu Teras Jati Doreng (Tectona grandis). Jurnal IImu Kehutanan 3(2): 67-73.

Lukmandaru G. 2013. The Natural Termite Resistance of Teak Wood Grown in Community Forest. Jurnal IImu dan Teknologi Kayu Tropis 11(2): 131-139.

Lukmandaru, G. 2010. Sifat Kimia Kayu Jati (Tectona grandis) pada Laju Pertumbuhan Berbeda. Jurnal IImu dan Teknologi Kayu Tropis. 8(2): 188-196.

Lukmandaru, G. 2011. Variability in the Natural Termite Resistance of Plantation Teak Wood and its Relations with Wood Extractive Content and Color Properties. Journal Forest Research 8(1): 17-31.

Lukmandaru, G. 2016. Hubungan antara Kadar Ekstraktif dengan Sifat Warna pada Kayu Teras Jati. Jurnal Penelitian Hasil Hutan 34(3): 207-216.

Lukmandaru, G.; P. Manalu, T. Listyanto; D. Irawati; R. Pujiarti; F. Hidayati; D. Rodiana. 2016. Chemical Properties of 15-year-old Teak (Tectona grandis L.f) from Different Seed Sources. Wood Research Journal 7(1): 6-12.

Lukmandaru, G.; I.G.N. Sayudha. 2019. Colour Properties and Extractive Content in Young Teak Woods. Proceeding of the $9^{\text {th }}$ International Symposium of Indonesian Wood Research Society. Denpasar. 26-27 September 2017, p. 164-174. 
Moya, R.; A. Berrocal. 2014. A Review of Heartwood Properties of Tectona grandis Trees from Fast-Growth Plantations. Wood Science and Technology 48: 411433.

Neverova, N.A.; A.A. Levchuk; L.A. Ostroukhova; E.N. Medvedeva; N.A. Onuchina; V.A. Babkin. 2013. Distribution of Extractive Substances in Wood of the Siberian Larch (Larix sibirica Ledeb.). Russian Journal of Bioorganic Chemistry 39(7): 712-719.

Niamke, F.B.; N. Amusant; J.P. Charpentier; G. Chaix; Y. Baissac; N. Boutahar; A.A. Adima; S. Kati-Coulibaly; C. Jay-Allemand. 2011. Relationships between Biochemical Attributes (Non-Structural Carbohydrates and Phenolics) and Natural Durability against Fungi in Dry Teak Wood (Tectona grandis L.f.). Annals of Forest Science 68: 201-21.

Niamké, F,B.; N. Amusant; D. Stien; G. Chaix; Y. Lozano; A.A. Kadio; N. Lemenager; D. Goh; A. A.A. Adima; S. Kati-Coulibaly, C. Jay-Allemand. 2012. 4',5'Dihydroxy-epiisocatalponol, a new naphthoquinone from Tectona grandis L. f. heartwood, and fungicidal activity. International Biodeterioration \& Biodegradation 74: 93-98.

Thulasidas, P.K.; K.M. Bhat. 2007. Chemical extractive compounds determining the brown-rot decay resistance of teak wood. Holz als Roh-und Werkstoff 65: 121-124.

Windeisen, E.; A. Klassen; G. Wegener. 2003. On the Chemical Characterization of Plantation Teakwood from Panama. Holzs als Roh und Werkstoff 61(6): 416-418.

Yamamoto, K.; H.M. Simatupang; R. Hashim. 1998. Caoutchouc in Teak Wood (Tectona grandis L.f.): Formation, Location, Influence on Sunlight Irradiation, Hydrophobicity, and Decay Resistance. Holzs als Roh und Werkstoff 56: 201-209.

Yunanta, R.R.K.; G. Lukmandaru; A. Fernandes. 2014. Sifat Kimia dan Kayu Shorea retusa, Shorea macroptera, dan Shorea macrophylla. Jurnal Penelitian Ekosistem Dipterokarpa 8(1): 15-24.

Zulkahfi; D. Irawati; T. Listyanto; D. Rodiana; G. Lukmandaru. 2020. Kadar Ekstraktif dan Sifat Warna Kayu Jati Plus Perhutani Umur 11 Tahun dari KPH Ngawi. Jurnal Ilmu Kehutanan 19(2): 213-227.

Ganis Lukmandaru, Alfian Nur Falaah, Tomy Listyanto Department of Forest Products Technology,

Faculty of Forestry, Gadjah Mada University

Jl. Agro, Bulaksumur, Sleman, Yogyakarta

Tel. : +62-274-512102

Fax. : : +62-275-550542

E-mail : glukmandaru@ugm.ac.id

Dian Rodiana

Research and Development Center, Perhutani, Central Java, 58203, Indonesia 